\title{
Roots of Violence by ISIS, An Analysis on Beliefs
}

\author{
Majid Bozorgmehri ${ }^{1}$ \\ ${ }^{1}$ Associate Professor, Political Sciences Department, Imam Khomeini International University, Qazvin, Iran \\ ${ }^{2}$ Visitor Scholar at York University, Toronto, Canada \\ Correspondence: Majid Bozorgmehri, Associate Professor, Political Sciences Department, Imam Khomeini \\ International University, Qazvin, Iran; Visitor Scholar at York University, Toronto, Canada.
}

Received: December 12, 2017

doi:10.11114/ijsss.v6i3.2877

\author{
Accepted: January 11, 2018 \\ Available online: February 2, 2018 \\ URL: https://doi.org/10.11114/ijsss.v6i3.2877
}

\begin{abstract}
ISIS was an Islamic fundamentalist organization which presents a radical version of Islamic beliefs, encourages holy violence, and considers others who do not agree with its understandings as apostates.

As a theoretical debate, the discussions developed by Gregg could cover the arguments stated through this study. He considers Social Movements, Fundamentalists, and Cosmic Warriors as the frameworks of religious cruelty.

Daesh`s Dogma could be analyzed in two levels: traditional platform and new generation literature. As the former, three pillars Salafism. Qutbism and Wahhabism shape the basements and frameworks of IS`s ideological structure. New generation literature, joined with an anti-western attitude and combined also with a Sense of revenge against the old powers of imperialism, justify the most violent acts everywhere.
\end{abstract}

As an alternative of being shaped in traditional dogma, ISIS's philosophy could be drawn from 3 new booklets. The Management of Savagery (Idarat al-tawahhush) written in 2000s by Abu Bakr al-Naji, is one of them.

For methodological aspect, the content analysis, concentrated on the basic sources is selected and for discussing the arguments, a descriptive analytical method is opted.

Keywords: Islamic State, Daesh, religious, violence, Middle East, Iraq, Syria

\section{Introduction}

\subsection{Statement of Problem}

ISIS was an Islamic fundamentalist organization. It presents a radical version of religion, encourages holy violence, and considers others who do not agree with its understandings as apostates. ISIS's ideology is rooted from one fraction of Islamic beliefs that intends for coming back to the primary times of Islam, refusing later novelties in the faith which it considers corrupt its intrinsic identity. It denounces later caliphates and the Ottoman Empire for getting away from what it knows as real faith and so has been endeavoring to launch a new caliphate in form of an Islamic State.

For some pundits, ISIL emerged from the beliefs of the Muslim Brotherhood, one of the post- Ottoman Islamist groups dating back to 1920s in Egypt. It follows the global jihadist principles and tracks the hardline dogma of al-Qaeda and a lot of jihadist organizations.

As the major question, I try to analyze the ideological roots of the violent activities by the Daesh. What are the religious principles which justify these violent behaviors and what does justify this high level of violence?

As my hypothesis, the roots of violent activities could be mostly traced in a socio-cognitive perceptual constructs. Traditional sources as well as the new generation literature shape the religious justifications. These, when combined with an anti-western attitude and covered with a sense of revenge against the old powers of imperialism, justify the most violent acts everywhere.

\subsection{Method of Research: Content Analysis}

Content analysis is firstly valuable in organizational research because it allows researchers to recover and examine the nuances of organizational behaviors, stakeholder perceptions, and societal trends. But it is also an important bridge between purely quantitative and purely qualitative research methods. In one regard, content analysis allows researchers to analyze socio-cognitive and perceptual constructs that are difficult to study via traditional quantitative archival 
methods. Here when we refer to the religious beliefs on violence and its roots, we are obliged to concentrate firstly on the holy texts for analyzing the behavior of believers as well as their socio-cognitive conceptions. So based on a content analysis, concentrated on the basic sources, I try to look at the roots. And for discussing the arguments, a descriptive analytical method is opted too.

\subsection{Review on Previous Literature}

There are many different arguments though, concerning the nature of the Islamic State in the Middle East. Most of them are directed by two models of explanation i.e. the chronological assessment and the linkages between two over lapping philosophical schools, salafism and wahhabism.

Bunzel through his interesting paper in 2015 sets forth the major outlines of the dogma of Daesh and follows its historical path. By a chronological consideration, Bunzel tries almost successfully to clarify the Daesh`s doctrines with a general assessment but the question of religious violence is not the main item.(Bunzel.2015)

Zhongmin by a comprehensive commentary on thoughts of Islamism has shown the gradual evolution of Islamic ideas during the last century. He has analyzed the Islamic State as a general conception form the point of view of the pioneers in the political Islam. (Zhongmin. 2013)

Wiktorowicz, by his discussion in 2005 on al Qaedeh`s justifications, tries to clarify the liens of violent acitivitis of al'Qaedeh and classical Islamic principles. According to him, understanding the genealogy of the radical jihadis necessitates identifying the key points of divergence within the Salafi community.(Wiktorowicz. 2005)

Blanchard emphasized on the strong linkages between Wahhabism and Salafism as the bases of violent fundamentalism.(Blanchard. 2008)

Ungureanu by study on the lines of Wahhabism and fundamentalist ideology in the contemporary evolutions of political Islam, attempts to demonstrate the expansion of Islamic fundamentalism through two frameworks. Wahhabism and Salafism characterized with an over lapping nature, according its opinion, shape the roots of Islamic fundamentalism. (Ungureanu.2008)

In our analysis, we have tried to concentrate on one aspect of Daesh`s activities, which is the roots of violence in conceptions and beliefs.

\subsection{Theoretical Debate: Case Corresponding on Three Theories}

While Brubaker seeks to develop a nuanced and competent account of the distinctive traditions in which religion can legitimize political conflict and violence,(Brubaker.2015) I prefer to concentrate on the discussions developed by Gregg, who considers Social Movements, Fundamentalists, and Cosmic Warriors as three theories of religious activism and violence.(Gregg.2013)

Gregg states some underlying frameworks for religious social and political action—social movements, fundamentalism, and Cosmic War-and the situations under which religious violence arise. The frameworks present a variety of aims for religious involvement, ranging from challenging social practices and government procedures, to defending specific versions and activities of the faith, to accelerating the apocalypse. Furthermore, each of these theories proposes different ways that religion becomes involved in social, political and religious activism and the conditions under which groups use violence to achieve their goals.(Gregg.2013) The Social Movement Theory offers cases of social movements that have recruit religion to shape, organize, and arrive to their objectives. The theory of fundamentalism speak about the patterns of fundamentalist activities and third theory looks at Mark Juergensmeyer's conception of Cosmic War and the conditions under which Cosmic War thinking emerge.

Cosmic War, an expression invented by sociologist Mark Juergensmeyer, is maybe the form of activism that is most frequently associated with religious violence. In "Sacrifice and Cosmic War,"Juergensmeyer claims that virtually all of the world's religious patterns contain scriptures and beliefs that describe divine fights between the forces of Good and Evil and that these battles are struggles to create "ultimate order" and conquer "ultimate disorder," which is death. (Juergensmeyer.1992) For many religions, the culmination of this battle is the belief in the end of times (such as the Apocalypse in Christianity, the End of Days in Judaism, the Last Judgment in Islam, and the arrival of Kalki, the tenth avatar of Vishnu in Hinduism), in which the final battle of Good vs. Evil will occur on this earth, and Good will triumph. (Gregg.2013) 
Table 1. The Comparison of Variables in Three Theories (Gregg. 2013)

\begin{tabular}{|l|l|l|l|l|l|}
\hline Type & Goal & Size & $\begin{array}{l}\text { Leadership } \\
\text { and } \\
\text { structure }\end{array}$ & Members & $\begin{array}{l}\text { Use of } \\
\text { Religion }\end{array}$ \\
\hline $\begin{array}{l}\text { Social } \\
\text { Movements }\end{array}$ & $\begin{array}{l}\text { Specific } \\
\text { and } \\
\text { limited }\end{array}$ & $\begin{array}{l}\text { Large } \\
\text { Highly } \\
\text { visible }\end{array}$ & $\begin{array}{l}\text { Charismatic } \\
\text { leader, } \\
\text { Possibly } \\
\text { leaderless }\end{array}$ & $\begin{array}{l}\text { Loose } \\
\text { affiliation } \\
\text { Porous } \\
\text { borders }\end{array}$ & $\begin{array}{l}\text { Mobilization } \\
\text { Legitimacy } \\
\text { Framing (not } \\
\text { necessary) }\end{array}$ \\
\hline $\begin{array}{l}\text { Fundamen- } \\
\text { talists }\end{array}$ & $\begin{array}{l}\text { Limited } \\
\text { but less } \\
\text { specific }\end{array}$ & $\begin{array}{l}\text { Small to } \\
\text { large with } \\
\text { clear } \\
\text { borders }\end{array}$ & $\begin{array}{l}\text { Charismatic } \\
\text { leader, } \\
\text { authoritarian }\end{array}$ & Committed & $\begin{array}{l}\text { Religion is } \\
\text { the core } \\
\text { issue } \\
\text { (orthodoxy } \\
\text { and } \\
\text { orthopraxy) }\end{array}$ \\
\hline $\begin{array}{l}\text { Cosmic } \\
\text { Warriors }\end{array}$ & $\begin{array}{l}\text { Vague } \\
\text { and } \\
\text { conflating } \\
\text { spiritual } \\
\text { with } \\
\text { earthly }\end{array}$ & $\begin{array}{l}\text { Small, can } \\
\text { be } \\
\text { clandestine }\end{array}$ & $\begin{array}{l}\text { Charismatic } \\
\text { leader, } \\
\text { prophetic }\end{array}$ & $\begin{array}{l}\text { Highly } \\
\text { committed } \\
\text { and } \\
\text { millennium }\end{array}$ \\
\hline
\end{tabular}

For the case of our study, a combination of three theories could be opted, because the religious violence of Daesh corresponds generally on each three frameworks.

\section{Data and Analysis}

ISIS is an Islamic Salafist-jihadi organization. Salafism is a fanatical Sunni political religious mobilization that looks for to revive the golden era of the dawn of Islam. That is to be done, by jihad (a holy combat) against both internal and external enemies.

For a comprehensive study on the framework of ideological concepts, two platforms should be distinguished, traditional and new generation literature.

\subsection{Traditional Platform}

\subsubsection{Salafism}

The Salafist school recognizes the era of the Prophet as the most perfect and the first Caliphs who succeeded him as prototypes. Salafism as a kind - despite its varieties - is marked in the belief that Islam reached its noblest and purest expression in Prophet Muhammad's own exemplary conduct (Sunnah), and those of his closest confidants and the first three generations of his successors known collectively as al-salaf al-salih (the pious ancestors). (Kamolnick.2017)

Salafism, as represented in the development of Islamic spirituality, maybe the most altered form of the Muslim culture, removing all values not connected with the first generations of Islam. Refusing the four Islamic doctrines- Hanafism, Malekism, Shafeism and Hanbalism - ,removing ethics and morality that have developed independently of the Quran. Salafism, sometimes called neo-fundamentalist Islamic ideology, is a Sunni Islamic movement that takes the pious ancestors as exemplary models (Salafi) of the patristic period of early Islam. (Wiktorowicz 2001, 65).

The modern Salafist wave initiated in Egypt, on consequence of the desire to purify Islam of its faults and return to what was perceived as the Golden Age of Islam.

Salafiyya is not a unified movement, and there exists no single Salafi "sect." (Blanchard.2008)

\subsubsection{Jihadi Salafism}

However, inside the Salafist dogma, a fanatical group called Salafiyya Jihadiyya (i.e., jihadi Salafism) arisen, from which Al-Qaeda and the global jihad organizations, including ISIS, have appeared. An ideologically important contribution to the expansion of the movement was made by Sayyid Qutb (1906-1966), an Egyptian ideologue whose ideas inspired the formation of Islamic organizations that supported violent fight. From a Salafist-jihadi viewpoint, Muslims must struggle to broadcast and implement Islam in all areas of life by liberating the lands of Islam from other cultures (especially Western culture) through jihad, which is supposed as the individual obligation (fard 'ayn) of all muslims. So each Muslim must combat the enemies of Islam through violent and uncompromising military fight. (Meir Amit.2014).

\subsubsection{Qutbism}

Qutbism (also called Kotebism, Qutbiyya, or Qutbiyyah) is an Islamist philosophy settled by late Sayyid Qutb, a Muslim, and figurehead of the Muslim Brotherhood (he was executed in 1966). It has been labeled as inspiring the extremist jihadist dogma of proliferating "offensive jihad. (Douglas.2007 ) Seyed Qutb`s reflections are formed through his 
membership in Muslim Brotherhood Organization, founded by Hassan Al-Banna (1906-1949). He as the founder of the Muslim Brotherhood, mainly demonstrated the necessity of rebuilding the Islamic state and Islamic order from the inclusiveness and self-sufficiency of Islam. He believed that "Islam is the unity of belief and leadership, religion and state, spirit and action, prayer and jihad, obedience and domination, the Koran and the sword" (Zhong, S., 1982: 39). He had such a definition of the goal of the Muslim Brotherhood: "Our duty as Muslim Brothers is to work for the reform of selves [nufus], of hearts and souls by joining them to Allah the all-high; then to organize our society to be fit for the virtuous community which commands the good and forbids the evil-doing, then from the community will arise the good state" (Zubaida, 1993: 48). Al-Banna believed that "the secret of Muslims' decline is that they have deviated from Islam." In order to get rid of backwardness, the Muslim community must be reformed, and the "reform should be based on Islamic religious rules and referees". He said that to achieve the reform goals, we must establish a real Islamic state and the Islamic order.(Zhongmin. 2013)

Sayyid Qutb's mature political views always concentrated on Islam - Islam as a complete system of morality, justice and governance, whose Sharia laws and principles should be the sole basis of governance and everything else in life - though his reading of it varied. Qutb's political philosophy has been described as an attempt to instantiate a complex and multilayer eschatological vision, partly grounded in the counter-hegemonic re-articulation of the traditional ideal of Islamic universalism.

On the issue of Islamic governance, Qutb differed with many modernist and reformist Muslims who claimed that democracy was Islamic because the Quranic institution of Shura supported elections and democracy. Qutb pointed out that the Shura chapter of the Qur'an was revealed during the Mekkan period, and therefore, it does not deal with the problem of government. It makes no reference to elections and calls only for the ruler to consult some of the ruled, as a particular case of the general rule of Shura.(Sivan. $1985: 73$ )

-Jahiliyyah versus freedom. This exposure to abuse of power undoubtedly contributed to the ideas in his famous prison-written Islamic manifesto "Ma 'alim fi-l-Tariq (Milestones), where he advocated a political system that is the opposite of dictatorship - i.e. one with no government. There Qutb argued: Much of the Muslim world approaches the Qur'an as a means to simply acquire culture and information, to participate in academic discussions and enjoyment. This evades the real purpose, for rather, it should be approached as a means to change society, to remove man from the enslavement of other men to the servitude of God.(Qutb.1957:7)

The way to bring about this freedom was for a revolutionary vanguard to fight jahiliyyah with a twofold approach: preaching, and abolishing the organizations and authorities of the Jahili system by "physical power and Jihad." (Qutb, Milestones. 63, .69)

\subsubsection{Wahhabism}

In the 1740s, Clerics in Mecca witness the emergence of a new dogma born in Central Arabia. The founder of the dogma, Muhammad ibn Abd al-Wahhab, declared that Muslims had reverted to idolatry.(Commins.2006)

Wahhabism (Arabic: يَياهو, Wahhābiya(h)) or Wahhabi mission (Commins. 2009 :ix) is a spiritual dogma or side-shoot of Sunni Islam.( Wahhbi.2005)

It has been variously defined as "orthodox", "ultraconservative" "austere", "fundamentalist","puritanical (or "puritan") as an Islamic "reform program" to restore "pure monotheistic worship" (tawhid), by clerics and as an "extremist pseudo-Sunni movement" by opponents. Adherents often object to the term Wahhabi or Wahhabism as derogatory, and prefer to be called Salafi or muwahhid. (Commins. 2009 :ix)) Wahhabism is named after an eighteenth century preacher and scholar, Muhammad ibn Abd al-Wahhab (1703-1792). He started a revivalist movement in the remote, sparsely populated region of Najd, encouraging an abolition of practices such as the popular "cult of saints", and shrine and tomb visit, widespread among Muslims, but which he considered idolatry, impurities and innovations in Islam.

The faithful adherents and followers furnish an essential re-statement of the orthodox Sunni fundamentals in their most rigorous form. Chief among al-Wahhab's contributions was his reconceptualization of the manner in which "faith" is to be proven as fact. This also applies to its opposite-Kufr (unbelief/infidelity), and whether takfir (apostasy, heresy) is declared against persons accused of such. Al-Wahhab professed that honest faith is not only a matter of an internal belief - belief of the heart or the mind — of those twin creedal essentials comprising the Shahada or first pillar of Islam-Allah is One, and Muhammad is his final messenger.

Wahhabis reject Islamic "theology" (kalam) in favor of strict textualism in understanding the Quran, and are sometimes described as being in the Athari school.(Halverson. 2010 :36)

For their guiding principles, the leaders of the Daesh, are open and clear about their almost exclusive commitment to the Wahhabi movement of Sunni Islam. The group circulates images of Wahhabi religious textbooks from Saudi Arabia in the schools it controls. (Kirkpatrick.2014) 
ISIL seeks to revive the original Wahhabi project of the restoration of the caliphate governed by strict Salafist doctrine, and following Wahhabi tradition, it accuses the followers of secular law as disbelievers.(al-Ibrahimi. 2014)

\subsection{New Generation Literature}

Rather than resort to widely known and eminent Muslim clerics, ISIS has refined its own scholarly experts, largely drawn from a younger generation. (Bunzel.2015)

Also, instead of being rooted in traditional dogma, ISIS's philosophy can be traced from 3 new booklets. The most well-known of them is The Management of Savagery (Idarat al-tawahhush) by a certain Abu Bakr al-Naji (a pseudonym), written in the early 2000s. This work is a strategic roadmap to creating an Islamic "state" that is different from the activities of former jihadist organizations. The Management of Savagery was distributed among ISIS fighters. (Weiss.2015:41)

Al-Naji's work is also somewhat different to those one finds in the classical Islamic tradition: it is immersed in realpolitik and short on religious doctrines. It is not unexpected that it has gained obtained a large number disciple among modern jihadist spheres.

As terrorism political analyst William McCants puts it: Despite Naji's insistence that jihadists are constrained by Islamic scripture, the "Islamic" principles he enunciated override the Prophet's strictures on violence [forbidding the targeting of civilians]. Maximum latitude for maximum violence is the real interpretive framework for Naji and his acolytes. (McCants. 2015:83)

Even the crucial term in the topic of al-Naji's work-al-tawahhush (which can be translated as "savagery," or "bestiality") — shows how far he gets away from the Islamic ideal of civilized, noble, and principled attitude, even, , in war situations.

The reputation of this manuscript between ISIS leaders, which they describe as "the first resource for mujahids in managing their areas of influence," is doubly enlightening, displaying the gravity of ISIS's misguidance.

Two other books held in high regard by ISIS leaders are Introduction to the Jurisprudence of Jihad by Abu Abdullah al-Muhajjer and The Essentials of Making Ready [for Jihad] by Sayyid Imam al-Sharif, known as Dr Fadl. According to Fawaz Gerges: The three booklets call for all-out war and try to persuade all for a full-scale

offensive jihad as opposed to defensive jihad in order to bleed the kuffar (infidels) or the enemies of Islam.(Gerges.2016:36)

The three booklets more than any classical work of Islamic jurisprudence, help to explain ISIS's brutal dogma and cruel methods.

\subsection{Legitimization of Violence}

\subsubsection{Takfir (Charge) All of Others as Infidels}

At the very center of ISIS's dogma is the theology inherited by its major forerunner and foundational ideologue, the Jordanian jihadist Abu Mus'ab al-Zarqawi-especially his understanding of takfir (declaring someone to be an apostate) and the killing of Shi'i Muslims on the basis of theology. (National Centre of Excellence for Islamic Studies. 2016)

In ISIS's view, it is very easy to leave the fold of Islam. For ISIS, failure to rule in accordance with a narrow definition of God's law constitutes unbelief.

(Dabiq.June-Jully2015)

This makes the Muslim Brotherhood and Hamas, among many others, traitors against Islam.(Dabiq.April-May 2016) Even fighting ISIS itself is equivalent to apostasy..(Al-Kiani. 2014) Indeed, Muslim "apostates" are the most common victims of ISIS's violence.

\subsubsection{Jihad}

Another main part of ISIS's dogma is its appeal for all Muslims to join the jihad. (National Centre of Excellence for Islamic Studies. 2016) This request

from ISIS and its fellow jihadists arises from a particular understanding of jihad as a permanent commitment — regardless of time or context-whenever "disbelief" is found. Disbelief is something that must be either completely eliminated or dominated. (Ali.2014)

Reading some of the classical fiqh texts literally, they claim that the caliph is committed to gather armies to mount regular raids on non-Muslim territories (dar al-kufr) to accomplish the sacred goals. (Al-Uyaari) 


\subsubsection{Violent Interpretation from Quran Verses}

With emphasis on Quran verses that speak of jihad and providing a fraudulent and extremist interpretation of them, they try to justify their violent activities. Emphasis on verses like:

1. Quran chapter 8 says, "(Remember) when your Lord inspired the angels, "Verily, I am with you, so keep firm those who have believed. I will cast terror into the hearts of those who have disbelieved, so strike them over the necks, and smite over all their fingers and toes" This is because they defied and disobeyed Allah and His Messenger. And whoever defies and disobeys Allah and His Messenger, then verily, Allah is Severe in punishment]"(Muhsin khan translated Quran, verse $8: 12-13)$

2. "Say to those who have disbelieved, if they cease (from disbelief) their past will be forgiven. But if they return (thereto), then the examples of those (punished) before them have already preceded (as a warning). And fight them until there is no more Fitnah (disbelief and polytheism: i.e. worshipping others besides Allah) and the religion (worship) will all be for Allah Alone [in the whole of the world]. (Muhsin khan translated Quran, verse 8:38-39)

So relying on one-sided interpretations, regardless of other verses or religious orders, leads to some radical commentaries which legitimize the violence.

\section{Conclusion}

The content of the Islamic State's ideology thus merits serious attention. This ideology could be analyzed on two levels: traditional platform and new literature. As the former, three pillars Salafism. Qutbism and Wahhabism build the basements and frameworks of IS`s ideological structure. New generation literature, joined with an anti-western attitude and covered also with a Sense of revenge against the old powers of imperialism, justify the most violent acts everywhere. Through the chart, the structure of violent act justifications which are rooted in religious beliefs and dogmas, are illustrated.

Chart No 1. Beliefs Legitimating Violence for Daesh

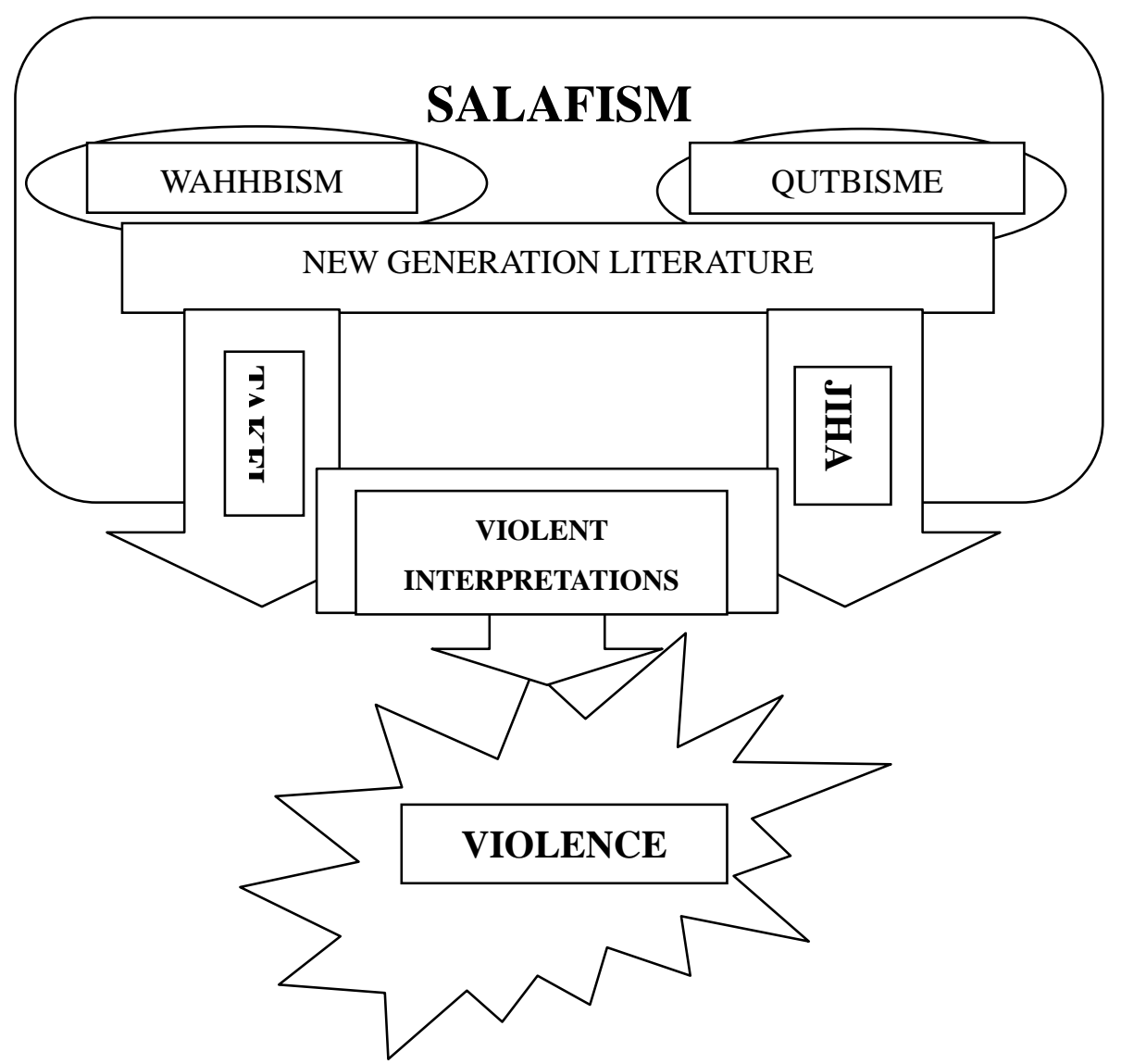

The Islamic State as a political entity, however, was inconceivable apart from its ideology. The group's senior leadership, by all appearances highly ideologically driven, settled the policies and direction of the group.

Supporters of IS point to its confrontation of Shiites, widely viewed as heretics by Wahhabis and Salafis; its return to the roots of Salafism, and its view of existing regimes as apostates. 
Salafism is an radical Sunni political religious movement within Islam that seeks to restore the golden era of the dawn of Islam. The followers of Salafism reject all innovations, all previous interpretations of Islam to them, which, paradoxically, lead to acceptance of some possibilities of interpretation (ijtihad) because there is no established authority to interpret the Qur'an and Sunna, the only sources they recognize.

Islamic State emphasizes the offensive form of jihad, which in the Wahhabi tradition is premised on the uprooting of shirk, idolatry, wherever it is found.

\section{Acknowledgement}

This research has been carried out during my sabbatical study nearby the department of Politics in York University in Canada and is granted by Imam Khomeini International University in Iran.

\section{References}

Ali, R., \& Stuart, H (2014). “A GUIDE TO REFUTING JIHADISM, Critiquing radical Islamist claims to theological authenticity”. Henry Jackson Society. January 2014 http://henryjacksonsociety.org/wp-content/uploads/2014/02/Refuting-Jihadism.pdf

Al-Ibrahim, F. (22 August, 2014). "Why ISIS is a threat to Saudi Arabia: Wahhabism's deferred promise". Al Akhbar (Lebanon). Retrieved 27 October 2014.

Al-Kiani, A. A. (2014). "It's Either the Islamic State or the Flood," Dabiq, no. 2, Ramadan1435/June-July 2014, 5-20, http://media.clarionproject.org/files/09-2014/isis-isil-islamic-state-magazine-Issue-2-the-flood.pdf; Dabiq, "The Extinction of the Grayzone," no. 7, Rabi'al - Akhir 1436/January-February 2015, 54-66, http://media.clarionproject.org/files/islamic-state/islamic-state-dabiq-magazine-issue-7-from-hypocrisy-to-apostasy .pdf

Al-Uyaari (rh). S. Y. (No date). "THE RULING ON JIHAD AND ITS DIVISIONS" Series of researches and studies in Shari'ah no. 2. Translated by Abu Osama1-8. http://islamicline.com/islamicbooks/The_Ruling_On_Jihad_And_Its_Divisions www.islamicline.com.pdf

Blanchard, C. M. (2008). "The Islamic Traditions of Wahhabism and Salafiyya" Foreign Affairs, Defense, and Trade Division. CRS Report for Congress. Order Code RS21695Updated January 24, 2008

Brubaker, R. (2015). “Religious Dimensions of Political Conflict and Violence”. Sociological Theory, 33(1), 1-19. () American Sociological Association, 2015. https://doi.org/10.1177/0735275115572153

Bunzel, C. (2015). "From Paper State to Caliphate: The Ideology of the Islamic State" (Washington, DC: Brookings Center for Middle East Policy, 2015), 11.

http://www.brookings.edu/ /media/research/files/papers/2015/03/ideology-of-islamic-state-bunzel/the-ideology-ofthe-islamic-state.pdf

Commins, D. (2006). “The Wahhabi Mission and Saudi Arabia”'ISBN 184511080 3. Published in 2006 by I.B.Tauris \& Co Ltd. 6 Salem Road, London W2 4BU. www.ibtauris.com

Dabiq, (2015). "The Law of Allah or the Laws of Men," no. 10, Ramadan 1436/June-July 2015, 50-64, http://www.clarionproject.org/docs/Issue\%2010\%20-\%20The\%20Laws\%20of\%20Allah\%20 or\%20the\%20Laws\%20of\%20Men.pdf.

Dabiq, (2016). "The Murtadd Brotherhood," no. 14, Rajab 1437/April-May 2016, 28-43, https://www.clarionproject.org/docs/Dabiq-Issue-14.pdf

Douglas, F. (2007). Qutbism and the Muslim Brotherhood by Douglas Farah http://counterterrorismblog.org/2007/05/qutbism_and_the_muslim_brother.php

Gerges, F. (2016). “ISIS: A History" (Princeton: Princeton University Press, 2016), 36. https://doi.org/10.1515/9781400880362

Gregg, H. S. (2013). "Social Movements, Fundamentalists, and Cosmic Warriors: Three Theories of Religious Activism and Violence". Defense Analysis Department. Naval Postgraduate School. Prepared for the ASREC Conference. April 11-14, 2013. Washington, DC.

Halverson, J. R. (2010). "Theology and Creed in Sunni Islam: The Muslim Brotherhood, Ash'arism, and Political Sunnism”, Palgrave Macmillan, ISBN 9780230106581. https://doi.org/10.1057/9780230106581

Juergensmeyer, M. (1992). "Sacrifice and Cosmic War," in Mark Juergensmeyer (ed.), Violence and the Sacred in the Modern World, New York: Routledge, 1992, pp. 106-111.

Kamonick, P. (2017). "THE AL-QAEDA ORGANIZATION AND THE ISLAMIC STATE ORGANIZATION: HISTORY, 
DOCTRINE, MODUS OPERANDI, AND U.S. POLICY TO DEGRADE AND DEFEAT TERRORISM CONDUCTED IN THE NAME OF SUNNI ISLAM". Strategic Studies Institute and U.S. Army War College Press. February 2017. ISBN 1-58487-744-8

Kane, O. ( 2007). “Moderate Revivalists: Islamic Inroads in Sub-Saharan Africa”.Harvard International Review 29.

Kirkpatrick, D. (2014). “Attacks in West Raise New Fears Over ISIS' Influence,” The New York Times, 24 October 2014

McAdam, D., McCarthy, J. D., \& Zald, M. N. (1996). “Comparative Perspectives on Social Movements: Political Opportunities, Mobilizing Structures, and Cultural Framings, ” New York: Cambridge. University Press, 1996.

McCants, W. (2015). “The ISIS Apocalypse: The History, Strategy, and Doomsday Vision of the Islamic State” (New York: St Martin's Press, 2015), 83. https://doi.org/10.1017/CBO9780511803987

National Center of Excellence for Islamic Studies (2016). “A RESOURCE FOR COMMUNITY LEADERS ISIS (ISLAMIC STATE OF IRAQ AND SYRIA) ORIGINS, IDEOLOGY, AND RESPONSES BY MAINSTREAM MUSLIM SCHOLARS”. 2016. The University of Melbourne Victoria 3010 Australia.

Qutb, S. (1957). “Milestones”. (معالم فى الطريق' )MAKTABAH .BOOKSELLERS AND PUBLISHERS. Birmingham England Maktabah Booksellers and Publishers.2006 ISBN: 0-9548665-1-7

Sivan, E. (1985). “Radical Islam: Medieval Theology and Modern Politics” (New Haven: Yale University Press, 1985),

The Meir Amit. (2014) “ISIS, Portrait of a Jihadi Terrorist Organization”. The Meir Amit Intelligence and Terrorism Information Center at the Israeli Intelligence and Heritage Commemoration Center

Ungureanu, D., \&Al, I. C. (2008). “Wahhabism, Salafism and the Expansion of Islamic Fundamentalist Ideology”. University of Iasi (Romania).

Weiss, M., \& Hassan. H. (2015). “ ISIS: Inside the Army of Terror” New York: Regan Arts,2015, 41.

Wiktorwicz, Q. (2005). “A Genealogy of Radical Islam”. Department of International Studies. Rhodes College. Memphis, Tennessee, USA. Studies in Conflict \& Terrorism, 28, 75-97, 2005. Taylor \& Francis Inc.. ISSN: 1057-610X print / 1521-0731 online. https://doi.org/10.1080/10576100590905057

Zhongmin, L. (2013). “Commentary on “Islamic State” Thoughts of Islamism”. Journal of Middle Eastern and Islamic Studies (in Asia), 7(3), 2013. Middle East Studies Institute, Shanghai International Studies University.

\section{Copyrights}

Copyright for this article is retained by the author(s), with first publication rights granted to the journal.

This is an open-access article distributed under the terms and conditions of the Creative Commons Attribution license which permits unrestricted use, distribution, and reproduction in any medium, provided the original work is properly cited. 